\title{
CONTRIBUTION AMONG JOINT TORTFEASORS AND THE MARITAL IMMUNITY
}

$\mathrm{P}$ ARALIELING THE TREND toward recognition of the right of contribution among joint tortfeasors, ${ }^{1}$ there has developed a widespread corollary limitation rooted in the concept of marital immunity. ${ }^{2}$ Thus, where Wife sues Stranger for damages for injuries sustained in an automobile accident which resulted from the concurrent negligence of Husband and Stranger, Stranger frequently can neither implead Husband in the initial suit nor, should Wife recover a judgment, seek contribution from him in a separate action thereafter. ${ }^{3}$

The recent concurrence of two New Jersey cases, ${ }^{4}$ arising under a newly adopted version of the Uniform Contribution Among Tortfeasors Act, ${ }^{5}$ pointedly demonstrates the logical and equitable insuffic-

\footnotetext{
${ }^{2}$ The Uniform Contribution Among Tortfeasors Act, 9 U.L.A. 156, was approved in 1939 by the National Conference of Commissioners on Uniform State Laws, and has, to date, been adopted in nine jurisdictions: ARK. STAT. \$\$ 34-roor34-1009 (194r); 10 DEL. C. \$\$ 6301-6308(1949); HAWAII REV. LAWS \$\$ I0487I0493 (1945); MD. CODE Art. 50, $\$ \$ 20-29$ (1950); N.J.S.A. 2A:53A-r-2A: 53 A-5 (I952); N.M. CoMP. L. \$\$ 21-II8-2I-I25 (1947); I2 PA. STAT. \$2082-2089 (195I); Rhode Island 1940 , c. 940 ; South Dakota r945, c. 167 .

2Any consideration of the marital immunity itself is beyond the scope of this note. See Prosser, TorTs $\S 99$, at $898-904$ (1941). In a state which allows tort actions to be brought directly by one spouse against the other there is of course, no objection to allowing the original defendant contribution against the concurrently negligent husband. Wait v. Pierce, r9r Wis. 202, 209 N.W. 475 (1926).

${ }^{3}$ Zutter v. O'Connell, 200 Wis. 60r, 229 N.W. 74 (1930) (no contribution against a father whose negligence contributed to the injury of his son); Ackerson v. Kibler, ${ }_{3} 8$ Misc. 695, 246 N.Y. Supp. 580 (Sup. Ct. 193 ), aff'd, 232 App. Div. 306, 249 N.Y. Supp. 629 (4th Dept., 193I); Norfolk Southern R. Co. v. Gretakis, r62 Va. 597, 174 S.E. 84 I (1934), notes 18 and 22 infra (defendant railroad could not implead father whose "gross negligence" contributed to the injury of his unemancipated daughter); Yellow Cab Co. of D.C., Inc. v. Dreslin, 86 App. D.C. 327, r8r F.2d 626, rg A.L.R.2d IooI (D.C. Cir. I950); Guerriero v. U-Drive It, 22 N.J. Super. 588,92 A.2d 140 ( 1952 ), note 26 infra. [This case, the first involving marital immunity to be decided under the New Jersey Contribution Act, is noted in 26 TEMP. L.Q. 453 (1953) ]; American Automobile Ins. Co. v. Molling, 57 N.W.2d 847 (Minn. I953), notes 15 and 20 infra; Ferguson v. Davis, I02 A.2d 707 (Del. Super. 1954). Contra: Fisher v. Diehl, I56 Pa. Super. 476, 40 A.2d 9r2 (r945), notes $\mathrm{I}_{2}$ and 24 infra.

4 Pennsylvania Greyhound Lines Co., Inc. v. Rosenthal, r4 N.J. 372, roz A.2d 587 (r954); Kennedy v. Camp, I4 N.J. 390, ro2 A.2d 595 (I954).

Joint Tortfeasors Contribution LAW, L. 1952, c. 335 , p. 1075, $\$$ I el seq.; N.J.S. 2A:53A-I et seq. (1952).
} 
ency of such a result. In Kennedy v. Camp, Stranger was denied contribution against Husband on the ground that joint and several liability of the tortfeasors to Wife was a substantive element of the right of contribution. $^{6}$ By way of justification, the court relied on the inadequately examined maxim that such a conclusion tended to preserve "the unity of the spouses which is interwoven into the law for the domestic peace and well-being that are conductive to the subsistence of the marriage relation."

In the companion case of Pennsylvania Greyhound Lines v. Rosenthal, ${ }^{8}$ however, the same court held that the right of contribution accrued to Stranger upon payment of the judgment and persisted even in the face of the judgment plaintiff's subsequent marriage to the joint tortfeasor. ${ }^{9}$ In thus concluding that Husband could not claim immunity from contribution by virtue of his subsequently acquired marital status, the court stated somewhat cryptically that "the considerations of marital immunity and domestic peace and felicity underlying the ancient policy interdicting actions between spouses have no place here."10

Analytically, the rationale of the Kennedy case, that enforcement of contribution against a spouse would impair the marital relationship by affording "the means of rendering the husband indirectly liable to his wife, "11 would seem to compel a contrary result in the Rosenthal case. Surely, Stranger's enforcement of contribution against Husband for a judgment paid to Wife before marriage would constitute no less an assault upon domestic tranquility than would enforcement of contribution for a judgment paid after marriage. ${ }^{12}$ Conversely, if, as stated in the Rosenthal case, contribution is an independent rather than derivative right and is "not to be confused with subrogation," then a

${ }_{14}$ N.J. 390 , I02 A.2d 595, 598 (I954).

${ }^{7}$ I02 A.2d at 599 (1954). ${ }^{8}$ I4 N.J. 372, I02 A.2d $5^{8} 7$ (1954).

'Similarly, in Godfrey v. Tidewater Power Co., 223 N.C. 647,27 S.E.2d 736 ( 1943$)$, it was held that the subsistence of the originally essential common liability was not necessary for the continuance of the independent cause of action to which it gave rise; and, therefore, the original defendant was allowed to implead the concurrently negligent municipality in favor of which the statute of limitations had run. In both the Godfrey and the Rosenthal cases, the court failed to consider whether the allowance of contribution might defeat the policy supposedly supporting the extinction of the common liability as much as a direct suit would have done.

${ }^{20}$ I4 N.J. 372, I02 A.2d 587, 595 (1954).

11 I4 N.J. 390, 102 A.2d 595, 599 (1954).

${ }^{12}$ In Fisher v. Diehl, I56 Pa. Super. $476,483,40$ A.2d 912, 9 I6 (r945), note 3 supra, note 24 infra, the court allowed the original defendant to implead the husband "provided that any judgment obtained against the husband, as additional defendant, may not be enforced by the wife-plaintiff, but is only available to the original defendant by way of contribution."

${ }^{23}$ I4 N.J. 372, ro2 A.2d 587,595 (1954). 
contrary result should follow in the Kennedy case, since Stranger's right of contribution there would be no less independent than that of his counterpart in the Rosenthal case. ${ }^{14}$

A logical contrariety appears from the juxtaposition of these two rationales, and the apparently antithetical holdings can be reconciled only superficially by an acceptance of the rule that common liability must originally exist to support later contribution. Inquiry into the history of the doctrine of contribution, however, reveals the limited justification for this requirement. ${ }^{15}$

Actions for contribution were first allowed in equity, as against coobligors on a contract, by any obligor who paid the entire amount due. This doctrine is said originally to have been "founded upon the principles of equity and natural justice, which require that those who voluntarily assume a common burden shall bear it in equal proportions." The fundamental basis of this right, then, was conceived to be the need for an equitable adjustment among the responsible parties. ${ }^{17}$ In its original suretyship context, however, an indispensible prerequisite to such a need was a common liability, the voluntary assumption of which alone defined the relations of the parties in all respects. In a tort context, on the other hand, since the mutual rights and duties of the joint tortfeasors are determined by law rather than by consensual arrangement, considerations of common liability to the injured party would seem to be quite irrelevant to an equitable adjustment reflecting the common responsibility of the joint tortfeasors for the tortious act, the character of which is not affected by marital immunity.

Most courts have failed to make this distinction. Instead, by an uncritical acceptance of common liability as "the very essence of the action of contribution," they have unnaturally warped its development

${ }^{14}$ Cf. Baltimore Transit Co. v. State, I83 Md. 674, 679, 39 A.2d 858, 860 (1944) (original defendant not allowed contribution from judgment plaintiff's employer since workmen's compensation precluded a common law action by the judgment plaintiff against his employer): "The right of contribution is a derivative right and not a new cause of action." But see, Central Banking \& Security Co. v. United States Fidelity \& Guaranty Co., 73 W.Va. I97, 207, 80 S.E. x21, 125 (1913) (a case involving contribution among sureties): "Nor is the right of contribution derived from the equitable principle of subrogation. Contribution and subrogation are separate and distinct things."

${ }^{15}$ A good review of the origins and foundations of the right of contribution is given by Loring, C.J., in American Automobile Ins. Co. v. Molling, 57 N.W.2d 847 (Minn. 1953), note 3 supra, note 20 infra.

${ }_{10} 1_{3}$ AM. JuR., Contribution $\S 4$.

${ }^{17}$ According to the Commissioners' Prefatory Note to the Uniform Contribution Among Tortfeasors Act, g U.L.A. 156, that which engendered the Act was "the desire for equal or proportionate distribution of a common burden among whom it rests." 
and engendered a technical discrimination not grounded upon policy factors of sufficient moment to justify it. Considered apart from abstract legal concepts, our sense of fairness rebels at the consequence-that Husband reaps an indirect profit from his own wrongdoing because of this unfortunate technicality. ${ }^{18}$

The ease with which legal obstacles to effective contribution may be surmounted varies, of course, among the several states according to their legal bases for the action. In a state such as Minnesota, where contribution has been extended to joint tortfeasors by the common law, ${ }^{10}$ a decision that this extension must invariably be attended by common liability restrictions ${ }^{20}$ would seem to be insupportable in light of what has been said above. In other states, such as Virginia, where the right is based upon statutory provision that "contribution among wrongdoers may be enforced when the wrong is a mere act of negligence and involves no moral turpitude, ${ }^{\prime 21}$ the interpolation of a common liability requirement ${ }^{22}$ would be equally or even more indefensible, since the remedial impact of a statute might conveniently provide the impetus necessary to effect a break with the old suretyship rules and to formulate a doctrine of contribution better designed for application in a torts context.

The most formidable obstacle, however, is encountered in the language of the Uniform Joint Tortfeasors Contribution Act and similar statutes in which the term "joint tortfeasors" is defined as "two or more persons jointly and severally liable in tort for the same injury" (emphasis added). ${ }^{23}$ The only court which has yet relied on such a statute to enforce contribution against a husband-tortfeasor ${ }^{24}$ passed

\footnotetext{
${ }^{18}$ Illustrative of the injustices which might result from the application of this marital immunity limitation is the holding in Norfolk Southern R. Co. v. Gretakis, 162 Va. 597, 174 S.E. 841 (1934), note 3 supra, note 22 infra. The court there held that the defendant railroad could not enforce contribution against the father whose gross negligence constituted $90 \%$ of the proximate cause of his unemancipated daughter's injury, notwithstanding the fact that the father was complctely covered by liability insurance.

${ }^{19}$ Duluth, M. \& N. R. Co. v. McCarthy, 183 Minn. 414, 236 N.W. 766 (1931). Other states which reached the same result without or before the aid of a statute are: Pennsylvania, Wisconsin, Louisiana, and perhaps Oregon. Prosser, Torts $\$ 109$, at III3-III4 (1941).

${ }_{20}$ American Automobile Ins. Co. v. Molling, 57 N.W.2d 847 (Minn. 1953), notes 3 and 15 supra.

${ }^{21}$ CODE OF VIRGINIA $§ 5779$ (I919); $88-627$, p. 439 (1950).

${ }^{22}$ Norfolk Southern R. Co. v. Gretakis, I 62 Va. 597, 174 S.E. 841 (1934), notes 3 and 18 supra.

${ }^{23}$ Uniform Contribution Among Tortfeasors ACT, 9 U.L.A. $156, \S$ I.

${ }^{24}$ Fisher v. Diehl, ${ }_{15} 6 \mathrm{~Pa}$. Super. 476, $40 \mathrm{A.2d} 912$ (1945), notes 3 and 12 supra. Although the Uniform Contribution Among Tortfeasors Act, 9 U.L.A. 156,
} 
over these words sub silentio, justifying its holding solely in terms of the essentially equitable nature of the action of contribution. ${ }^{25}$ Such a solution seems scarcely satisfactory. ${ }^{26}$ Equally liberal courts, feeling impelled to reach the same result in a more straightforward way, might perhaps interpret "liable" to mean "responsible" within the meaning of the act; ${ }^{27}$ but such a circumvention seems artificial and vulnerable to attack as judicial legislation. The greater likelihood rather appears to be that the courts, when faced with the words of such a statute, will resign themselves to the inexorable import of the language, adhere to the position of Kennedy $v$. Camp and rule in the final analysis that the remedy must lie with the legislature. ${ }^{28}$

Russell M. Robinson

had not been adopted in Pennsylvania at that time, the Fisher case was decided under the act of June 24, I939, P.L. I075, I2 PA. STAT. $§ 208$ I (I940), which provided: "Contribution shall be enforcible among those who are jointly or severally liable for a tort."

${ }_{26}$ Fisher v. Diehl, $156 \mathrm{~Pa}$. Super. $476,487,49$ A.2d 912, 917 (1945). The court stated: "We are of the opinion that the bringing in of [Husband] as an additional defendant in the action brought by his wife against [Stranger] was in the interest of right and justice, and that to have refused to have done so would have been an injustice to the original defendant; and that as no harm or injury resulted therefrom to the plaintiff, the judgment should be affirmed."

${ }^{20}$ The court, in American Automobile Ins. Co. v. Molling, 57 N.W.2d 847, 853 (Minn. 1953), disposed of the contrary decision in Fisher $v$. Diehl, supra note 25, with the observation that "the case fails to discuss the 'common liability' element of the action of contribution." And in Guerriero v. U-Drive It Co. of New Jersey, 22 N.J. Super. $588,602,92$ A.2d 140, 147 (1952), note 3 supra, the court distinguished the Fisher case by noting that the decision was reached "under Pennsylvania statutes, but such could not occur under our Joint Tortfeasors Contribution Act with its definition of 'joint tortfeasors' and 'joint liability." "

${ }^{27}$ In Gray v. Hartford Accident \& Indemnity Co., 3 I F. Supp. 299, 306 (D.C. La. 1940), the only case yet to arise in which the marital immunity as a bar to the right of contribution between tortfeasors has been evaded on strictly technical grounds, the federal court to which the action had been removed because of diversity of citizenship found that the plaintiff-wife had a substantive claim in tort against her husband [CIv. CODE LA. Art. 2402 (1932)], but that their marriage constituted a procedural bar to this substantive right. CODE OF PRACTICE LA. Art. 105 (1932). The court held, however, that this procedural barrier raised by the Louisiana statute was not presented by Rule $\mathrm{I}_{4}$ of the Federal Rules of Civil Procedure. Therefore, the original defendant was entitled to implead the husband of the plaintiff-wife because "we are to apply the substantive law of the state and the procedural law of the federal courts,"

${ }^{28}$ Justice Jacobs recognized in his special concurring opinion in Kennedy $v$. Camp, 14 N.J. 390, r02 A.2d 595, 60I-602 (1954), that "such policy as may possibly prevail against tort actions between spouses clearly has no bearing on situations which do not involve any direct proceedings between them as adverse party litigants;" and consequently he dissented "to the extent that the majority opinion suggests a contrary view." Considering, however, that the "statutory language is not sufficiently broad to extend to the instant case" he felt compelled to agree with the conclusion of the majority. 